University of Wollongong

Research Online

Faculty of Engineering - Papers (Archive)

Faculty of Engineering and Information

Sciences

$1-1-2011$

\title{
Treatment of acidic groundwater in acid sulfate soil terrain using recycled concrete: column experiments
}

\author{
Gyanendra Regmi \\ University of Wollongong, gr524@uowmail.edu.au \\ Buddhima Indraratna \\ University of Wollongong, indra@uow.edu.au \\ Long Nghiem \\ University of Wollongong, longn@uow.edu.au
}

\author{
A. Golab \\ University of Wollongong, golab@uow.edu.au \\ B Guru Prasad \\ gurubpch@lycos.com
}

Follow this and additional works at: https://ro.uow.edu.au/engpapers

Part of the Engineering Commons

https://ro.uow.edu.au/engpapers/916

\section{Recommended Citation}

Regmi, Gyanendra; Indraratna, Buddhima; Nghiem, Long; Golab, A.; and Guru Prasad, B: Treatment of acidic groundwater in acid sulfate soil terrain using recycled concrete: column experiments 2011, 433-443.

https://ro.uow.edu.au/engpapers/916

Research Online is the open access institutional repository for the University of Wollongong. For further information contact the UOW Library: research-pubs@uow.edu.au 


\title{
TREATMENT OF ACIDIC GROUNDWATER IN ACID SULPHATE SOIL TERRAIN USING RECYCED CONCRETE: COLUMN EXPERIMENTS
}

\author{
Gyanendra Regmi ${ }^{1}$, Buddhima Indraratna (FASCE) ${ }^{1}$, Long Duc Nghiem ${ }^{1}$, and Alexandra \\ $\mathrm{Golab}^{2}$ \\ ${ }^{1}$ School of Civil, Mining \& Environmental Engineering, \\ University of Wollongong, Wollongong, NSW 2522, Australia \\ ${ }^{2}$ DigitalCore Pty Ltd, Canberra, ACT 2601, Australia.
}

Number of words: 5,901

Number of tables: 2

Number of figures: 12

Total Words Equivalent: 10,533

Author for correspondence:

Prof. Buddhima Indraratna

Faculty of Engineering,

University of Wollongong

Wollongong, NSW 2522

Australia

Ph.: +612 42213046

Fax: +61 242213238

Email: $\underline{\text { indra@uow.edu.au }}$

Submitted to ASCE Journal of Environmental Engineering 


\title{
TREATMENT OF ACIDIC GROUNDWATER IN ACID SULPHATE SOIL TERRAIN USING RECYCED CONCRETE: COLUMN EXPERIMENTS
}

\author{
Gyanendra Regmi ${ }^{1}$, Buddhima Indraratna (FASCE) ${ }^{1}$, Long Duc Nghiem ${ }^{1}$, and Alexandra \\ $\mathrm{Golab}^{2}$
}

\begin{abstract}
Acidic groundwater generated from pyrite oxidation in acid sulphate soil (ASS) is a major geoenvironmental problem in Australia. This study aims to evaluate recycled concrete as a reactive material in permeable reactive barriers (PRBs) for the remediation of acidic groundwater in lowlying ASS floodplains. Laboratory experiments were systematically conducted to investigate the acid neutralisation behaviour of recycled concrete and its potential to remove dissolved Al and Fe. The results confirmed that recycled concrete could effectively treat acidic groundwater from an ASS terrain, resulting in near-neutral effluent over a long period with complete removal of Al and Fe. The major mechanisms involved in neutralising acidic groundwater are thought to be the precipitation of $\mathrm{Al}$ and $\mathrm{Fe}$ as oxides, oxy-hydroxides and hydroxides. However, the accumulation of secondary minerals could decrease the reactivity of the recycled concrete. Indeed, chemical armouring could decrease the neutralising capacity of recycled concrete by up to $50 \%$ compared to the theoretical acid neutralisation capacity of this material. The results reported here also show that the neutralisation capacity and reactive efficiency of recycled concrete are dependent on not only the initial $\mathrm{pH}$ value but also the concentration of both $\mathrm{Al}$ and $\mathrm{Fe}$ in the acidic groundwater. Key Words: Acid sulphate soil, armouring, column tests, permeable reactive barrier (PRB), recycled concrete.
\end{abstract}

${ }^{1} \mathrm{PhD}$ candidate, School of Civil, Mining and Environmental Engineering, University of

Wollongong, NSW 2522, Australia, email: gr524@uow.edu.au

${ }^{2}$ Professor, School of Civil, Mining and Environmental Engineering, University of 
Wollongong, NSW 2522, Australia, email: indra@uow.edu.au

${ }^{3}$ Senior Lecturer, School of Civil, Mining and Environmental Engineering, University of

Wollongong, NSW 2522, Australia, email: $\underline{\text { longn@uow.edu.au }}$

${ }^{4}$ Analyst, DigitalCore Pty Ltd, Canberra, ACT 2601, Australia, email:

alexandra.golab@digitalcorelabs.com 


\section{INTRODUCTION}

Environmental problems associated with acid sulphate soils (ASS) have been widely identified in coastal Australia since the 1960s. Sulphidic soil is commonly exposed to air due to the excessive use of large-scale artificial drainage to reclaim land for development and agriculture (White et al. 1997). The oxidation of residual sulphide minerals such as pyrite in the vadose zone of ASS terrains can produce acidic pore waters which can mobilise potentially toxic metals such as aluminium ( $\mathrm{Al}$ ) and iron (Fe) from the soil (Indraratna et al. 2005). Infiltration of such acidic and metal-rich water into aquifers and discharge to nearby surface water bodies can lead to adverse environmental and social impacts such as incompatibility of land and groundwater for agriculture and aquaculture, and ecological disturbance in surface water ecosystems (Sammut et al. 1996). Therefore, discharge from acid sulphate soil can be an intractable environmental issue in many coastal regions around the world.

Although the causes of acidic waters, namely oxidation of pyrite, have been studied extensively for more than five decades including the conditions and parameters that promote oxidation reaction (Singer and Stumm 1970; White et al. 1997), limited studies have been conducted for their remediation. Recently, low cost engineering techniques (e.g. inundation of the vadose zone in ASS terrain and brackish water neutralisation via weirs and floodgate modification respectively) have been used to diminish the oxidation of ASS and improve the drainage water quality (Blowes et al. 2003; Indraratna et al. 2005; Golab and Indraratna 2009). Fixed level weirs raise the watertable which then inundates the ASS and prevents some oxidation (Blunden and Indraratna 2001), while modified two-way floodgates buffer acidity due to the tidal ingress of brackish water (Glamore and Indraratna 2004). However, these techniques are not practical in low-lying areas of ASS terrain because of the elevated risk of flooding during heavy rainfall events, an inability to prevent oxidation of the pyritic layer far away from the drain, and the possibility of regenerating large amounts of acid in the soils by dissolution of Fe precipitates such as jarosite. Alternatively, soil liming to neutralise the soil and groundwater acidity has also been practiced. Such an approach can be effective but often involves high operating costs and produces metal-rich sludge in the soil (Benner et al. 1999), from which metals may subsequently leach when mixed with freshly produced acid in the groundwater. These conventional strategies target acidity production along the hydro-geological pathway from the soil profile to the discharge point, but do not address the acidity already present in the soil and groundwater. 
In such low-lying floodplains, the application of permeable reactive barriers (PRBs) for remediating acidic groundwater might be an effective and inexpensive alternative to these conventional techniques. Laboratory and field studies have established the potential utility of this remedial method for different organic and inorganic contaminants such as radionuclides, heavy metals and acid mine drainage (Blowes et al. 2000; Gu et al. 2002; Jurjovec et al. 2002; Waybrant et al. 2002). Laboratory batch studies on 23 different alkaline materials, including several waste materials, showed that recycled concrete has an enormous potential for neutralising acidic water and can be a suitable reactive material for treating acidic groundwater (Golab et al. 2006). However, the results of the batch tests could not confirm the longevity of the material because of the static nature of the tests, whereas the reactivity in the field would decrease over time due to the continuous flow of acidic groundwater over the surface of the reactive material. Three short-term column tests were performed to test the neutralisation behaviour of two reactive materials, including recycled concrete (Golab et al. 2009). Based on these tests, a pilot-scale PRB filled with recycled concrete was installed on a low-lying floodplain in coastal southeast New South Wales, Australia (Regmi et al. 2009). The barrier, which was installed in 2006, has shown a significant increase in the $\mathrm{pH}$ of the groundwater and a reduced concentration of both $\mathrm{Al}$ and Fe downgradient of the PRB. However, the precipitates formed in the PRB during neutralisation of the acidic water could cause extensive armouring over time, which would in turn decrease the treatment capacity of the materials by decreasing the exposed surface area of the reactive media. Furthermore, fine precipitates forming inside the PRB and filling the pore space between the reactive media may alter the groundwater flow paths through the barrier $(\mathrm{Li}$ and Benson 2005). Thus, excessive precipitation inside the barrier may threaten its longevity. Similar failures have occurred in several oxic limestone drains used to remediate acid mine drainage (Watzlaf et al. 2000).

In this study, column experiments were conducted to evaluate the reactive potential of recycled concrete to neutralise the acidity of ASS groundwater under dynamic flow conditions. The performance of recycled concrete was systematically assessed by varying the concentrations of $\mathrm{Al}$ and $\mathrm{Fe}$ in simulated ASS groundwater. Geochemical reactions underlying the neutralisation of acidic groundwater by recycled concrete were suggested and discussed in detail. The Al and Fe removal capacity of the recycled concrete from the ASS groundwater was examined. Potential 
effects of chemical armouring and physical clogging of the recycled concrete were also studied to evaluate the overall longevity of this reactive material.

\section{MATERIALS AND METHODS}

\section{REACTIVE MATERIALS}

The concrete aggregates used in this investigation were collected from a refuse depot, after the demolition of old concrete structures, and were then crushed to smaller particle sizes to suit the column (Figure 1). This was the same batch of recycled concrete used in the pilot PRB described in Regmi et al. (2009). Poorly gravel-sized particles (GP) according to the Unified Soil Classification System (ASTM D2487) (Figure 1) were used for all the tests reported here because the study did not cover the effect of particle size distribution on reactivity. The chemical composition of the major cations present in the recycled concrete is shown in Figure 2. The large calcium content indicates that it can generate significant amounts of alkalinity to neutralise the acidic water (Golab et al. 2006).

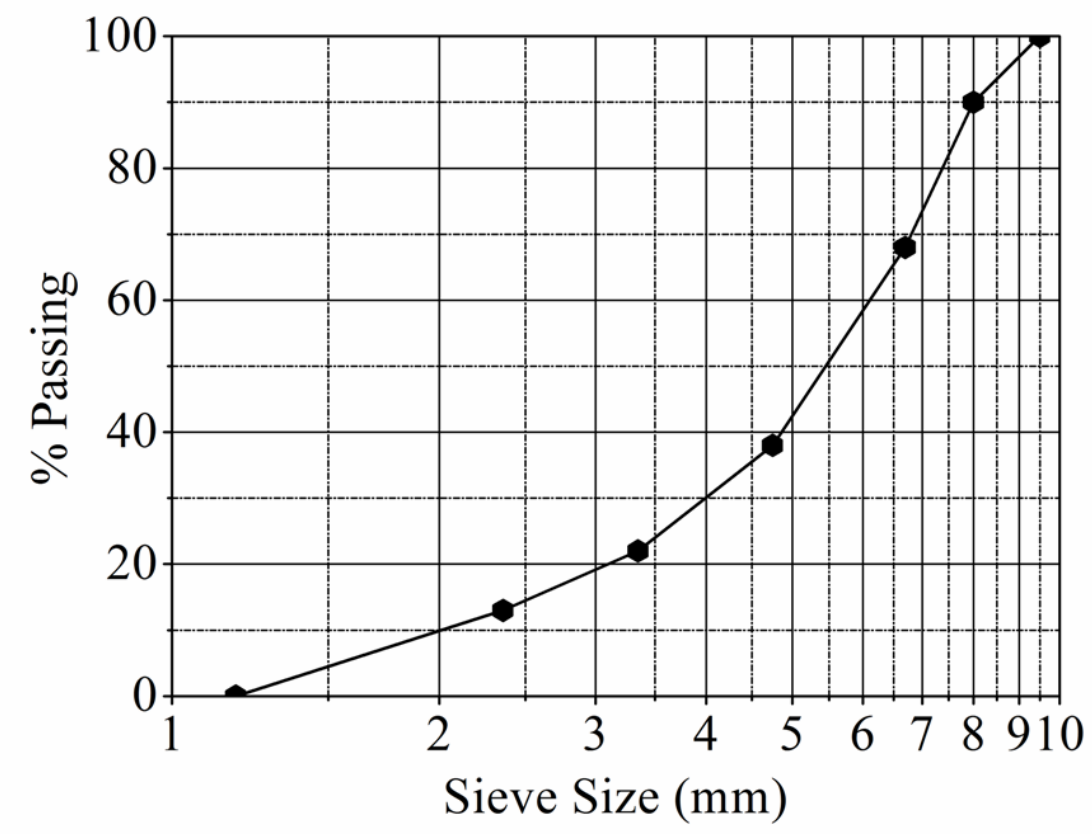

Fig. 1. Particle-size distribution of the recycled concrete used in column experiments. 


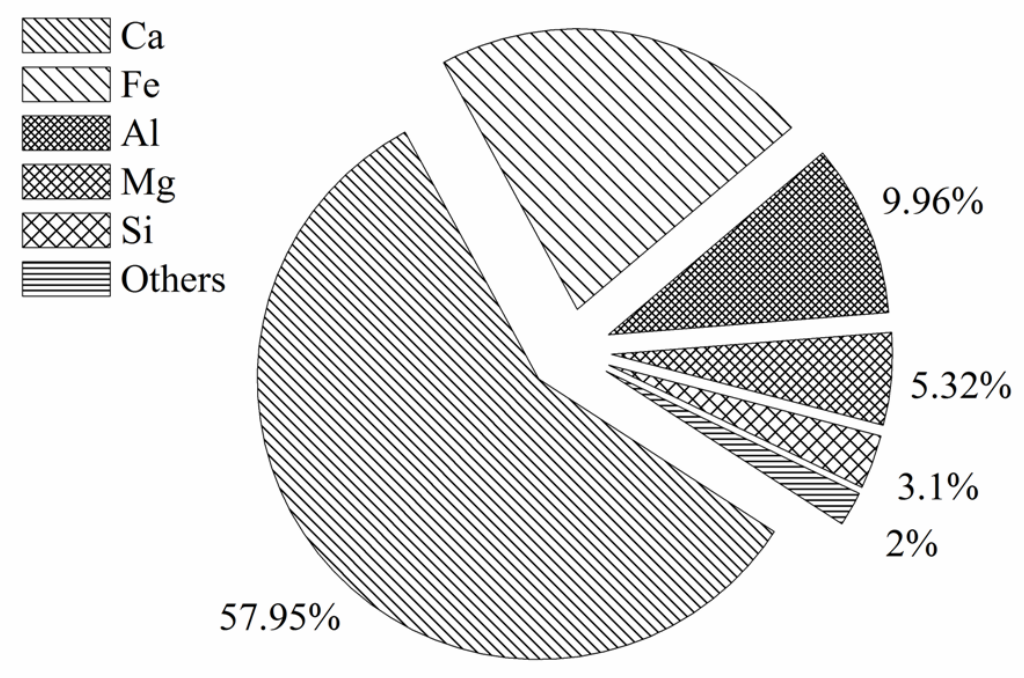

Fig. 2 Elemental composition of the recycled concrete used in the column experiments.

\section{SYNTHETIC ACIDIC GROUNDWATER}

Four synthetic acidic groundwater solutions were prepared for four corresponding columns identified as $\mathrm{A}, \mathrm{B}, \mathrm{C}$, and $\mathrm{D}$ (Table 1) to elucidate the roles of $\mathrm{Al}$ and Fe during the remediation process. With the exception of $\mathrm{Al}$ and $\mathrm{Fe}$, the concentrations of all other major constituents of these solutions were identical to the average values of the actual groundwater collected from an ASS site in the Shoalhaven region, south-eastern NSW (Regmi et al. 2009). The solution used in column A had the same concentrations of $\mathrm{Al}$ and $\mathrm{Fe}$ as the average values of the ASS groundwater. The remaining three columns were used to elucidate the impact of $\mathrm{Al}$ and $\mathrm{Fe}$ on the reactivity of the material by increasing the concentration of one or both of these cations. The concentrations of $\mathrm{Al}$ and $\mathrm{Fe}$ used in column $\mathrm{B}$ were increased by approximately 10 and 30 times respectively compared to the average groundwater values for simulating the effects of high concentrations of these metals on the performance of the reactive material. Columns $\mathrm{C}$ and $\mathrm{D}$ were conducted with a solution containing only one of these cations, i.e. either $\mathrm{Al}$ or Fe. The concentrations of these cations were the highest values recorded in the ASS by Regmi et al. (2009) and were approximately 10 times that of the average ASS groundwater solution in the field. 
Table 1: (a) Physical parameters of the column experiment, and (b) Composition of the influent water used for the column experiments for simulating the acidic groundwater in ASS terrain observed by Regmi et al. (2009)

\begin{tabular}{|c|c|c|c|c|}
\hline Parameters & Column A & Column B & Column C & Column D \\
\hline \multicolumn{5}{|l|}{ (a) Physical parameters of columns } \\
\hline Porosity (\%) & 53 & 48 & 56 & 55 \\
\hline Mass of concrete $(\mathrm{kg})$ & 1.200 & 1.321 & 1.258 & 1.283 \\
\hline Flow rate $(\mathrm{mL} / \mathrm{min})$ & 2.4 & 2.4 & 1.18 & 1.18 \\
\hline Acid Neutralisation Capacity $(\mathrm{g} / \mathrm{Kg})$ & 146 & 146 & 146 & 146 \\
\hline \multicolumn{5}{|l|}{ (b) Composition of influent } \\
\hline $\mathrm{pH}$ & 2.67 & 1.87 & 2.12 & 3.18 \\
\hline $\begin{array}{l}\text { Acidity corresponding to } \mathrm{pH} 7 \\
\left(\text { meq } \mathrm{CaCO}_{3}\right)\end{array}$ & 6.45 & 63.45 & 29.80 & 29.60 \\
\hline $\mathrm{Na}^{+}(\mathrm{mM})$ & 19.14 & 19.14 & 19.14 & 19.14 \\
\hline $\mathrm{K}^{+}(\mathrm{mM})$ & 1.07 & 1.07 & 1.07 & 1.07 \\
\hline $\mathrm{Ca}^{2+}(\mathrm{mM})$ & 2.84 & 2.84 & 2.84 & 2.84 \\
\hline $\mathrm{Mg}^{2+}(\mathrm{mM})$ & 3.7 & 3.7 & 3.7 & 3.7 \\
\hline $\mathrm{Al}^{3+}(\mathrm{mM})$ & 1.5 & 16.47 & 0 & 16.47 \\
\hline Total Fe (mM) & 1.5 & 43.5 & 16.47 & 0 \\
\hline $\mathrm{Cl}^{-}(\mathrm{mM})$ & 23.0 & 23.0 & 23.0 & 23.0 \\
\hline $\mathrm{SO}_{4}{ }^{2-}(\mathrm{mM})$ & 12.10 & 12.10 & 12.10 & 12.10 \\
\hline
\end{tabular}

\section{EXPERIMENTAL PROTOCOL}

The experiments were conducted in four transparent, acrylic columns $(\mathrm{L}=65 \mathrm{~cm}, \mathrm{I} . \mathrm{D} .=5 \mathrm{~cm})$ filled with recycled concrete. The physical parameters of the packing materials, flow rate and composition of synthetic groundwater in these columns are shown in Table 1. Each column was packed with $10 \mathrm{~cm}$ of silica sand at the bottom, followed by $50 \mathrm{~cm}$ of recycled concrete, and then topped with $5 \mathrm{~cm}$ silica sand. The influent and effluent ports were separated from the silica sand using a geotextile to prevent physical clogging by the sand. Piezometers were fitted at the top and bottom interface between the reactive media and sand zones to observe any change in head due to clogging inside the column. Masterflex peristaltic pumps (Figure 3) were used to pump synthetic acidic water up through the columns at a constant flow rate as shown in Table 1. 


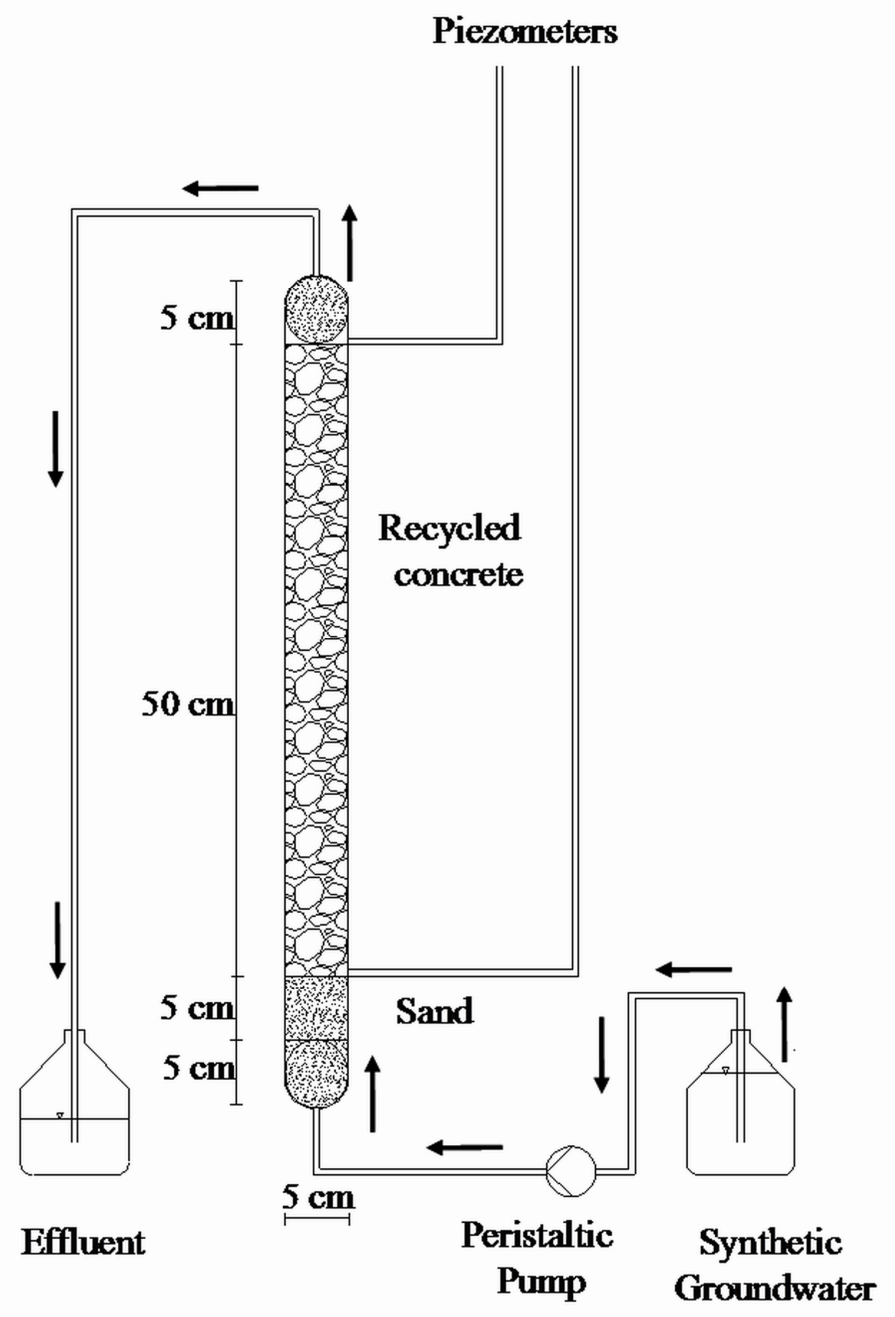

Fig. 3. Schematic diagram of the laboratory column setup 
Table 2: Composition of precipitates $(\mathrm{g} / \mathrm{kg})$ collected from different zones in the column $\mathrm{A}$ after the completion of the experiment

\begin{tabular}{|c|r|r|r|}
\hline Elements & Zone 1 $(0-10 \mathrm{~cm})$ & Zone 2 $(10-30 \mathrm{~cm})$ & Zone 3 $(30-50 \mathrm{~cm})$ \\
\hline $\mathrm{Na}$ & 0.2 & 0.2 & 0.3 \\
\hline $\mathrm{K}$ & 0.6 & 0.5 & 0.6 \\
\hline $\mathrm{Mg}$ & 2.6 & 2.5 & 3.2 \\
\hline $\mathrm{Ca}$ & 6.6 & 5.3 & 12.1 \\
\hline $\mathrm{Fe}$ & 231.1 & 226.7 & 148.5 \\
\hline $\mathrm{Al}$ & 67.1 & 88.9 & 143.4 \\
\hline $\mathrm{Cl}$ & 0.1 & 0.1 & 0.1 \\
\hline $\mathrm{S}$ & 13.7 & 18.4 & 17.3 \\
\hline $\mathrm{Total} \mathrm{C}$ & 5.1 & 2.9 & 3.5 \\
\hline Sum & 327.1 & 345.5 & 325.8 \\
\hline
\end{tabular}

Sampling ports were located in column A at 2.5, 10, 20, 30, 40, 50 and $55 \mathrm{~cm}$ (outlet) from the bottom interface of the reactive media and sand zone to study the acid neutralisation behaviour of recycled concrete. Effluent samples were only collected at the outlet from the remaining three columns. The packed columns were flushed with 4 to 5 pore volumes (PV, defined here as the void volume of the column) of de-ionised water before commencing the experiments. All column studies were conducted at room temperature. $\mathrm{pH}$ and oxidation reduction potential (ORP) were measured immediately after the samples were collected. Acid neutralisation capacity (ANC) of the material was analysed by following the Acid Sulphate Soil Laboratory Method Guidelines 2004 (Ahern et al. 2004), and all other chemical analyses (acidity, alkalinity, major cations, major anions and other trace metals) were performed following the standard method for the examination of water and wastewater (APHA 1998). 


\section{MINERALOGICAL ANALYSIS}

The geochemical speciation/mass transfer computer code PHREEQC V2.15 (Parkhurst and Appelo 1999) with MINTEQA database was used to calculate the Saturation Index (SI) (Eq. 1) of minerals in equilibrium within the effluent.

$\mathrm{SI}=\log \mathrm{IAP}-\log \mathrm{K}_{\mathrm{sp}}$

where IAP = ion activity product, and $\mathrm{K}_{\mathrm{sp}}=$ solubility constant

With respect to a particular mineral, an SI value of zero indicates equilibrium, a positive value indicates over-saturation, and a negative value indicates under-saturation. SI values for various mineral phases were calculated for the column effluent with the input parameters $\mathrm{Na}^{+}$, $\mathrm{K}^{+}, \mathrm{Ca}^{2+}, \mathrm{Mg}^{2+}, \mathrm{Al}^{3+}, \mathrm{Fe}^{3+}, \mathrm{Cl}^{-}, \mathrm{SO}_{4}^{2-}$, alkalinity, $\mathrm{pH}, \mathrm{ORP}$ and temperature.

When the experiment was completed, column A was drained slowly, kept air dry for three weeks and then samples of the reactive materials with precipitates were extracted. Samples were extracted from three zones (bottom zone: ports at 0 to $10 \mathrm{~cm}$, middle zone: ports at 10 to 30 $\mathrm{cm}$ and top zone: ports at 30 to $50 \mathrm{~cm}$ ). Solid samples fouled with precipitates and samples of virgin concrete from the same batch were collected for analysis using a Scanning electron microscopy (SEM) and Energy dispersive spectroscopy (EDS). Each sample was mounted on an aluminium stub, carbon coated with a carbon sputter coater and then vacuum-impregnated in epoxy. The samples were then examined by an SEM equipped with an EDS analyser and the results of both were compared to characterise the precipitates. The remaining solid samples collected from different parts of the column were placed inside three beakers, washed several times with deionised water and filtered with $0.45 \mu \mathrm{m}$ filter paper under pressure until the colour of the effluent was clear. The extracted precipitates were oven dried and then acid digested in 1:1 $\mathrm{HNO}_{3} / \mathrm{HCl}$ acid and analysed by Inductively coupled plasma-mass spectrometry (ICP-MS) following APHA 3120 to confirm the success of the reactive material in removing the contaminants as well as confirming the results of equilibrium modelling.

\section{RESULTS AND DISCUSSION ACID NEUTRALISATION BEHAVIOUR}

A step-wise decreased $\mathrm{pH}$ profile was observed in all four columns as the number of pore volumes passed through the column increased (Fig. 4). The $\mathrm{pH}$ of the effluent collected from all four columns was high ( $\mathrm{pH}$ 11.2) at the beginning of the experiment, but then dropped sharply 
and remained almost neutral for a considerable number of PVs, depending on the content of Al and $\mathrm{Fe}$ in the groundwater. The $\mathrm{Al}$ and $\mathrm{Fe}$ in all four column tests were completely removed during this first acid neutralisation stage. Nevertheless, the detailed acid neutralisation behaviour among the four columns investigated in this study differed markedly. Indeed, the acid neutralisation behaviour of each column can be related very well to the content of $\mathrm{Al}$ and/or Fe in the influent.
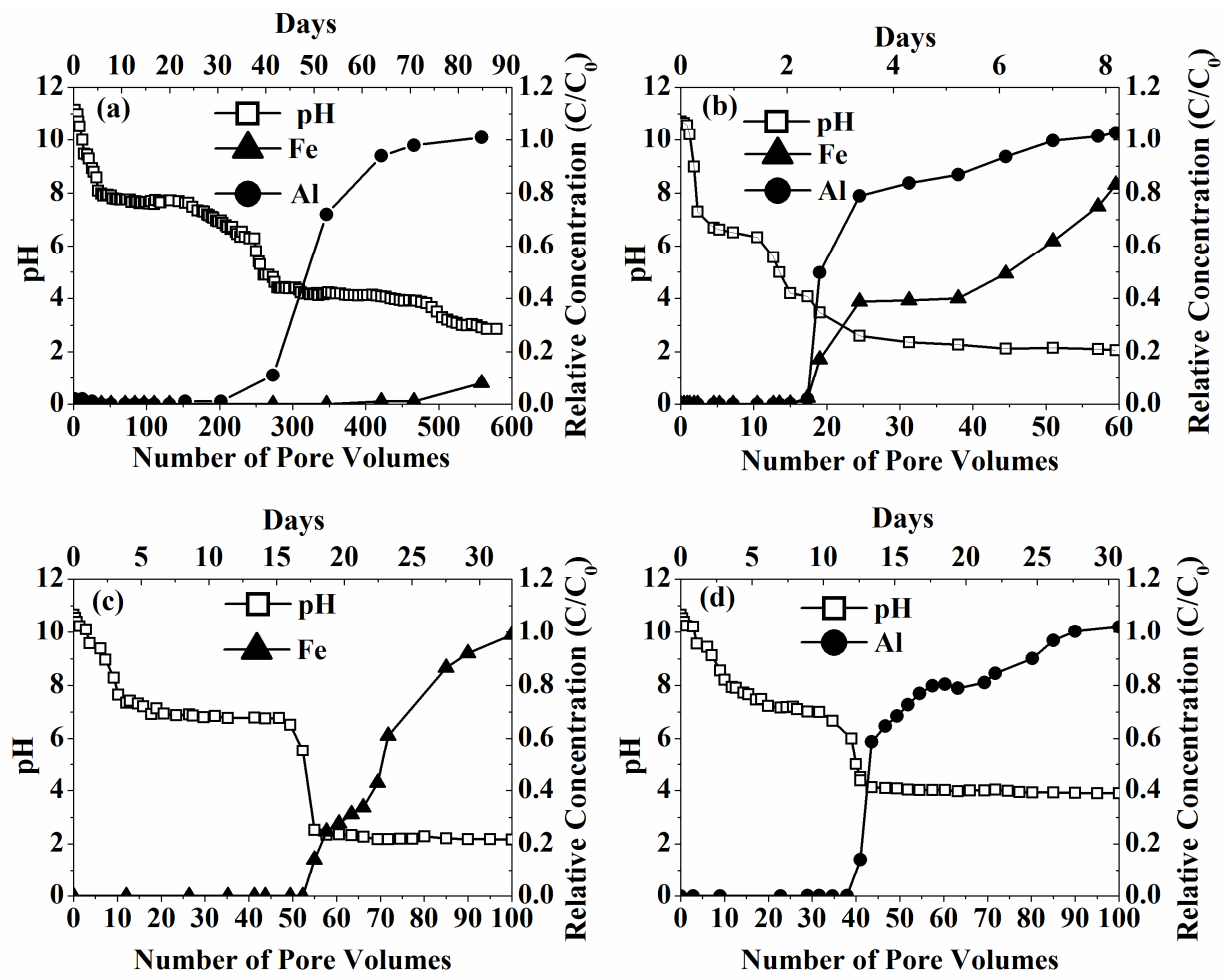

Figure 4: Study of the performance parameters of the recycled concrete under different concentrations of Fe and Al (a-d represents the columns A-D) with respect to the number of pore volumes of acidic groundwater and time

In column A, there were three long plateaux (Fig. 4a): (1) $\mathrm{pH}$ at $\sim 7.9$ to 7.7 for $40<\mathrm{PV}$ $<155$, followed by a gradual decrease in $\mathrm{pH}$ towards $\mathrm{pH} \sim 6.5$ at $\mathrm{PV} \sim 235$, (2) $\mathrm{pH}$ at $\sim 4$ for $300<$ $\mathrm{PV}<500$ and (3) $\mathrm{pH} \sim 2.7$ after 500 PVs; where the $\mathrm{pH}$ dropped from one plateau to another over just a few PVs. All three pH plateaux, similar to column A, were also observed in column B, but for much lower PVs (Fig. 4b: the first plateau from 3-11 PV, the second from 15-18 PV and the third from 25 PV onward). In contrast, there were only two pH plateaux in Columns C (Fig. 4c: the first plateau from 11-50 PV, the second from 53 PV onward) and D (Fig. 4d: the first plateau 
from 11-35 PV, the second from $43 \mathrm{PV}$ onward). This was due to the absence of one of the acidic cations (Fe and $\mathrm{Al}$, respectively) in these columns.

Although the influent of columns C and D had nearly the same acidity, the influent of column $\mathrm{C}$ had a lower $\mathrm{pH}$ than column D. However, the $\mathrm{pH}$ of the effluent in column $\mathrm{C}$ dropped from the first to the second plateau (at $50 \mathrm{PVs}$ ) slightly later than column D (at $35 \mathrm{PVs}$ ). As elaborated later, this is because of the different reaction kinetics of the two elements $\mathrm{Fe}$ and $\mathrm{Al}$ precipitating during the acid neutralisation process. The Fe minerals have lower equilibrium constants than the $\mathrm{Al}$ minerals. For example $\log \mathrm{K}_{\mathrm{eq}}$ for $\mathrm{Fe}$ minerals such as goethite and ferrihydrite are -1 and 3.0 - 5.0, respectively, whereas $\log \mathrm{K}_{\mathrm{eq}}$ for $\mathrm{Al}$ minerals such as gibbsite and bohemite are 7.83 and 7.94 respectively (Blowes et al. 2003). This difference in equilibrium conditions indicates that the reaction rate of the $\mathrm{Fe}$ in column $\mathrm{C}$ was slower than the $\mathrm{Al}$ in column D for both precipitation and dissolution of minerals. Therefore, the consumption of alkalinity and growth of precipitates in column $\mathrm{C}$ were found later than in column $\mathrm{D}$, which resulted in a longer duration of the first $\mathrm{pH}$ plateau in column $\mathrm{C}$. Furthermore, the $\mathrm{pH}$ of the second plateau was lower in column $\mathrm{C}(\mathrm{pH} \sim 2.5$ - 2.3) than column $\mathrm{D}$ ( $\mathrm{pH} \sim 4.3$ - 4.0) presumably because (i) the $\mathrm{pH}$ for maintaining equilibrium with $\mathrm{Al}$ minerals (i.e. $\mathrm{pH} 4.0$ ) is always higher than the $\mathrm{pH}$ for maintaining equilibrium with Fe minerals ( $\mathrm{pH} \sim 2.8$ and below) (Johnson et al. 2000) and (ii) the higher pH of the influent in column D than column C. In all four columns, the recycled concrete successfully removed $\mathrm{Al}(>99 \%)$ and $\mathrm{Fe}(100 \%)$ until the $\mathrm{pH}$ dropped to $2^{\text {nd }}$ and $3^{\text {rd }}$ plateau respectively (Fig.4).

In addition, columns B-D maintained an almost neutral $\mathrm{pH}$ value for lower PVs than did column A, because the acidity in these columns was much higher than in column A (Table 1). More importantly, the continuous flow of such highly acidic water with large amounts of Al and/or Fe favoured a fast growth of large amounts of precipitates inside columns B-D within a smaller number of PVs, which would have further decreased the reactivity of the reactive material. This chemical armouring effect is discussed further in a later section.

Overall, the three different plateaux in $\mathrm{pH}$ can be attributed to three distinct $\mathrm{pH}$-buffering reactions: (1) the dissolution of carbonate/bicarbonate alkalinity from concrete at nearly neutral $\mathrm{pH}$, (2) re-dissolution of aluminium hydroxide precipitates at $\mathrm{pH} \sim 4$, and (3) re-dissolution of ferric oxyhydroxides minerals at $\mathrm{pH}<3$. 


\section{Bicarbonate Buffering}

Among the three proposed buffering reactions, the first one (i.e. carbonate/bicarbonate buffering) was the most significant for remediating acidic groundwater because of the maintenance of an almost neutral $\mathrm{pH}$ and complete removal of the $\mathrm{Al}$ and Fe from the solution. The most abundant alkalinity generating minerals in the recycled concrete responsible for maintaining alkaline to near neutral $\mathrm{pH}$ of the effluent are the cementitious minerals present in the concrete, which consist of portlandite $\left(\mathrm{Ca}(\mathrm{OH})_{2}\right)$ and calcium aluminate hydrated compounds $(\mathrm{C}-\mathrm{A}-\mathrm{H})$. In addition, some calcium carbonate may have already formed in the waste concrete aggregate due to the carbonation of these minerals present in hydrated cement materials (Tam et al. 2005).

The effluent from column A produced by flushing with de-ionised water just before the experiment commenced had a high $\mathrm{pH}(\sim 11.2)$ due to the dissolution of a minor amount of portlandite, which when reacted with acid, maintained alkaline $\mathrm{pH}(\mathrm{pH}$ above 8.3) until 40 PVs corresponding to an ORP of $50 \mathrm{mV}$ initially, which indicates a weak oxidising conditions inside the column (Figs. 5a, b). As shown by Eqs. 2 and 3, hydroxyl and carbonate alkalinity are released by the dissolution of portlandite and carbonation, respectively.

$$
\begin{aligned}
& \mathrm{Ca}(\mathrm{OH})_{2}+2 \mathrm{H}^{+} \rightarrow \mathrm{Ca}^{2+}+2 \mathrm{H}_{2} \mathrm{O} \\
& \mathrm{Ca}(\mathrm{OH})_{2}+\mathrm{CO}_{2} \rightarrow \mathrm{CaCO}_{3}+\mathrm{H}_{2} \mathrm{O}
\end{aligned}
$$

\section{Days}

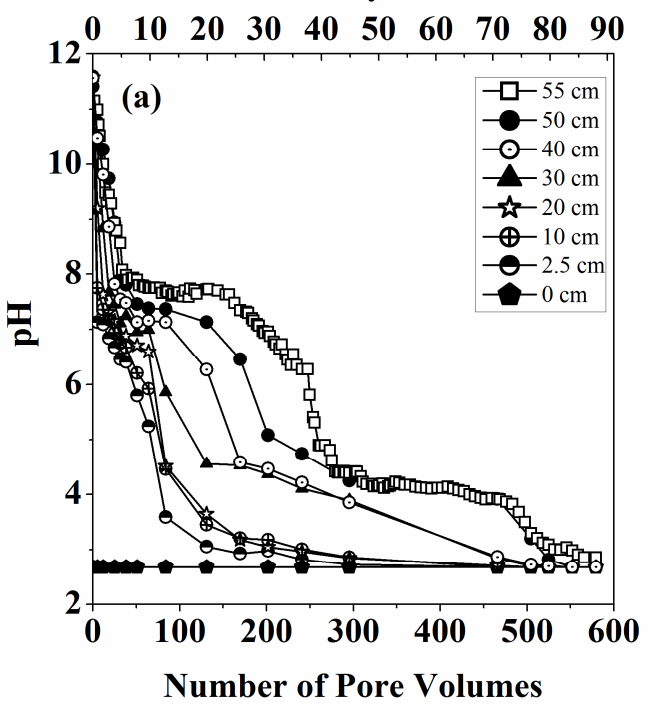

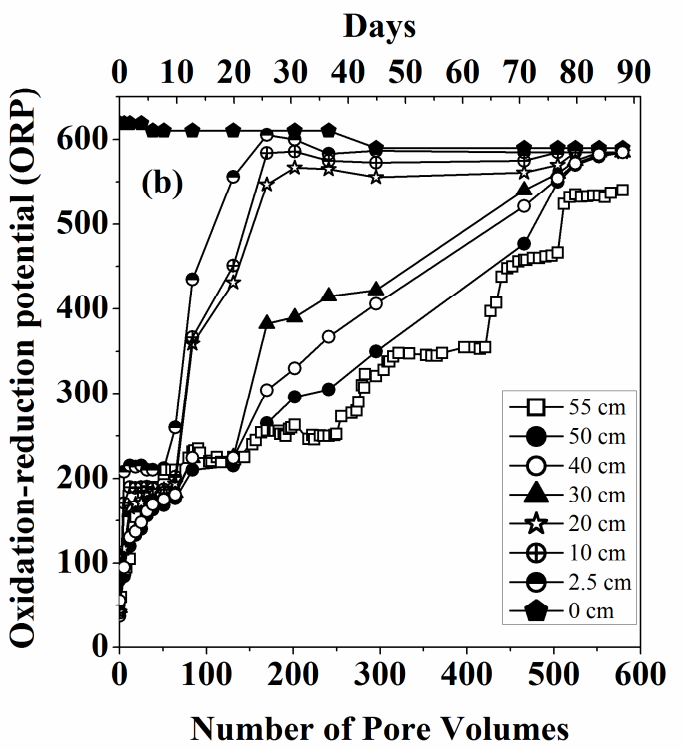

Figure 5: (a) $\mathrm{pH}$ and (b) oxidation-reduction potential (ORP) profiles along the length of the column with respect to number of pore volumes of acidic groundwater passed in column A and time. 
In absence of bicarbonate alkalinity, total alkalinity released $\left(70 \mathrm{mg} / \mathrm{L}\right.$ as $\left.\mathrm{CaCO}_{3}\right)$ was not strong enough to buffer the $\mathrm{pH}$ for a long period resulting in a rapidly decreasing $\mathrm{pH}$ such that this buffering action is not significant for acid neutralisation. In addition, total alkalinity decreased due to the precipitation of calcite during this buffering. Subsequently, the $\mathrm{pH}$ of the effluent remained near neutral value ( $\mathrm{pH} \sim 6.5$ - 7.9) until about $250 \mathrm{PVs}$ (Fig. 5a) due to the progressive dissolution of $\mathrm{C}-\mathrm{A}-\mathrm{H}$ with continuous contact of acid over the reactive media, in accordance with the following equation.

$$
\mathrm{CaAl}_{2} \mathrm{SiO}_{8}+8 \mathrm{H}^{+} \rightarrow \mathrm{Ca}^{2+}+2 \mathrm{Al}^{3+}+2 \mathrm{H}_{4} \mathrm{SiO}_{4}
$$

Inversely, the ORP of the effluent increased slightly at the start of the experiment and remained quite stable $(<250 \mathrm{mV})$ during this stable $\mathrm{pH}$ phase, which indicated that weak oxidising conditions dominated.

The carbonate alkalinity rapidly diminished once acidic water was passed through the column and changed to bicarbonate alkalinity within approximately 40 PVs in accordance with Eqs. 5-7, resulting in an increase in alkalinity of the system.

$$
\begin{aligned}
& \mathrm{CaCO}_{3}+2 \mathrm{H}^{+} \Leftrightarrow \mathrm{Ca}^{2+}+\mathrm{H}_{2} \mathrm{CO}_{3} \\
& \mathrm{CaCO}_{3}+\mathrm{H}_{2} \mathrm{CO}_{3} \Leftrightarrow \mathrm{Ca}^{2+}+2 \mathrm{HCO}_{3}^{-} \\
& \mathrm{CO}_{2}+\mathrm{H}_{2} \mathrm{O} \Leftrightarrow \mathrm{H}_{2} \mathrm{CO}_{3}
\end{aligned}
$$

Dissolution of the ca-bearing minerals from the concrete as shown in Eqs. 4-7 released calcium and increased the alkalinity with a potential to maintain the $\mathrm{pH}$ of the water to near neutral. Fig. 6 shows the alkalinity generated and calcium released from the recycled concrete. Both parameters in the effluent increased until 160 PVs, and then decreased, supporting the hypothesis for reactions 4-7. Al et al. (2000) observed that armouring the reactive carbonate mineral grains by the accumulated secondary mineral precipitates during the acid neutralization period in sulfide-rich mine tailings diminished the rates of mass transfer between primary minerals and pore water, thereby reducing the rate of primary mineral dissolution. Similar to this, in column A, when the mineral precipitates gradually coated the surface of the recycled concrete, pH decreased slowly as a function of dimensionless time (i.e. PV) from the first plateau at PV 155, reaching pH 6.5 at 250 PVs. This mechanism was supported by a decrease in alkalinity as shown in Fig 6. Immediately before the depletion of alkalinity, the $\mathrm{pH}$ was relatively stable and 
near neutral, varying from 7.9 to 6.5 . The $\mathrm{pH}$ then dropped abruptly reaching the next plateau ( $\mathrm{pH} 4.2$ - 4.0) after the complete depletion of bicarbonate alkalinity at 300 PVs.

As shown in Fig.5 for column A, the $\mathrm{pH}$ at different sampling ports decreased rapidly in the lower parts of the column with increasing PVs, corresponding to a sharp increase in ORP due to a fast depletion of alkalinity at the advancing acid front. As a result of the decrease in $\mathrm{pH}$ (Fig. 5a) and increase in ORP (Fig. 5b), depletion of both the alkalinity generation and calcium released from the system (Fig. 6) were slower in the top part of the column relative to the bottom part of the column. For example, near neutral $\mathrm{pH}$ was continuously maintained for $250 \mathrm{PVs}$ for the outlet port at $55 \mathrm{~cm}$ due to continuous release of alkalinity, whereas the alkalinity depleted to 0 at 84 and $202 \mathrm{PVs}$ for ports at 2.5 and $30 \mathrm{~cm}$, respectively from the interface between the bottom layer of concrete and sand. With the continuous passage of acid through column A, a total depletion of alkalinity from the column was accompanied by a sharp decline in $\mathrm{pH}$ to $\sim 4.0$ and an increase in ORP within the next $50 \mathrm{PVs}$ of acid passed, justifying the aforementioned assumptions for carbonate/bicarbonate buffering reactions. In good agreement with this study, Johnson et al. (2000) and Jurjovec et al. (2002) observed a similarly stable pH behaviour during the generation of carbonate/bicarbonate alkalinity followed by a rapid drop in $\mathrm{pH}$ after the total depletion of these carbonate minerals in acid mine drainage.

The increase in $\mathrm{pH}$ due to acid neutralisation reactions can lead to a pronounced decline in the concentration of dissolved metals due to precipitation. However, the observed concentrations of the $\mathrm{Mg}^{2+}, \mathrm{Na}^{+}, \mathrm{K}^{+}, \mathrm{Cl}^{-}$and $\mathrm{SO}_{4}{ }^{2-}$ in the effluent and influent were relatively constant throughout the entire experiment (Fig. 7a), which indicates they were unaffected by the neutralisation reactions. Similar to our study, Watzlaf et al. (2000) also reported in the study of 10 different anoxic limestone drains (ALDs) that $\mathrm{SO}_{4}{ }^{2-}$ levels were unaffected by the ALDs. In contrast, the near complete removal of $\mathrm{Al}(>99 \%)$ and Fe (100\%) (Fig. 7b) during this bicarbonate buffering period ( $<300 \mathrm{PVs})$ in column A indicated that the $\mathrm{Al}$ and Fe precipitated out of solution. 

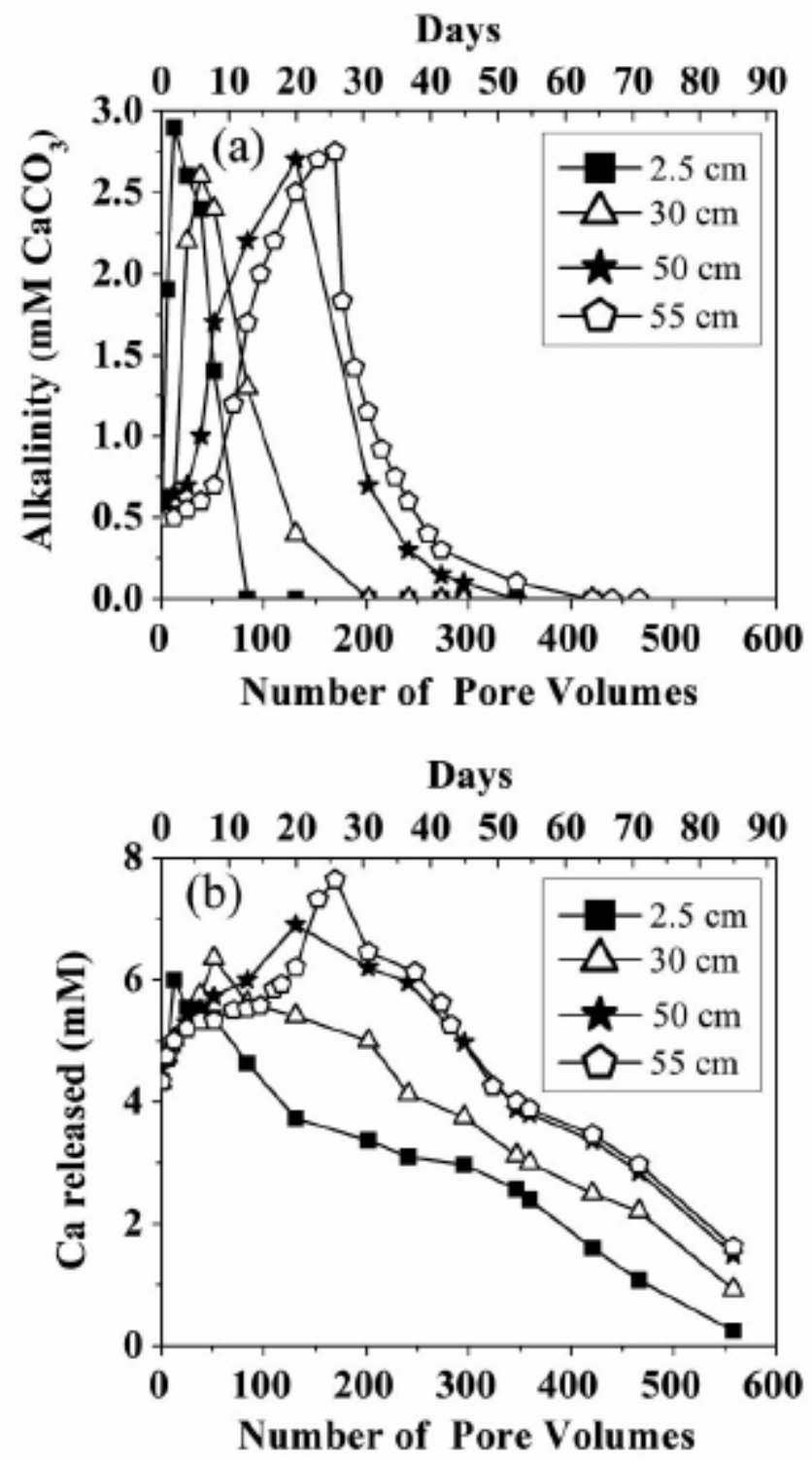

Figure 6: (a) Alkalinity and (b) Calcium released along the length of the column from the recycled concrete with respect to the number of pore volumes of acidic groundwater passed in column $\mathrm{A}$ and time. 

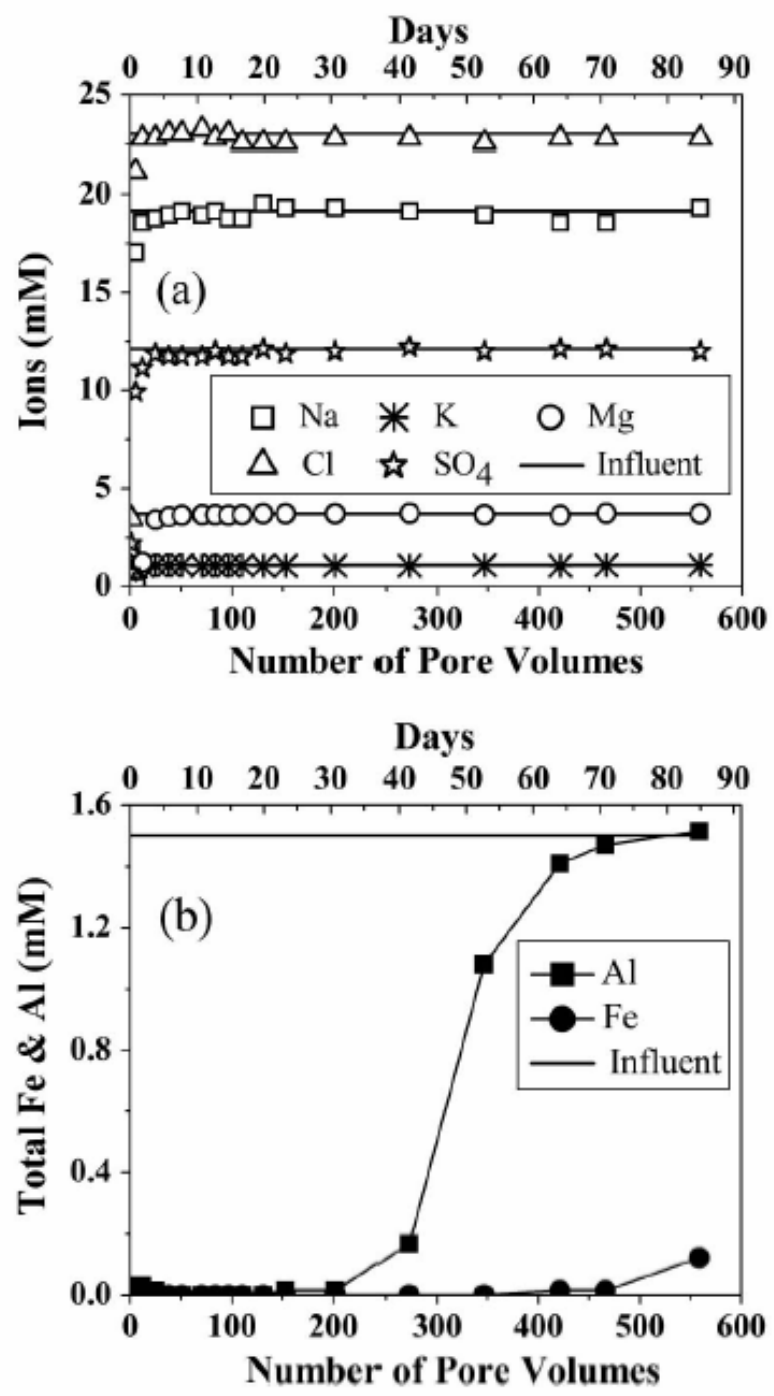

Figure 7: Ions concentrations for the influent and effluent with respect to the number of pore volumes of acidic groundwater passed in column A and time. 

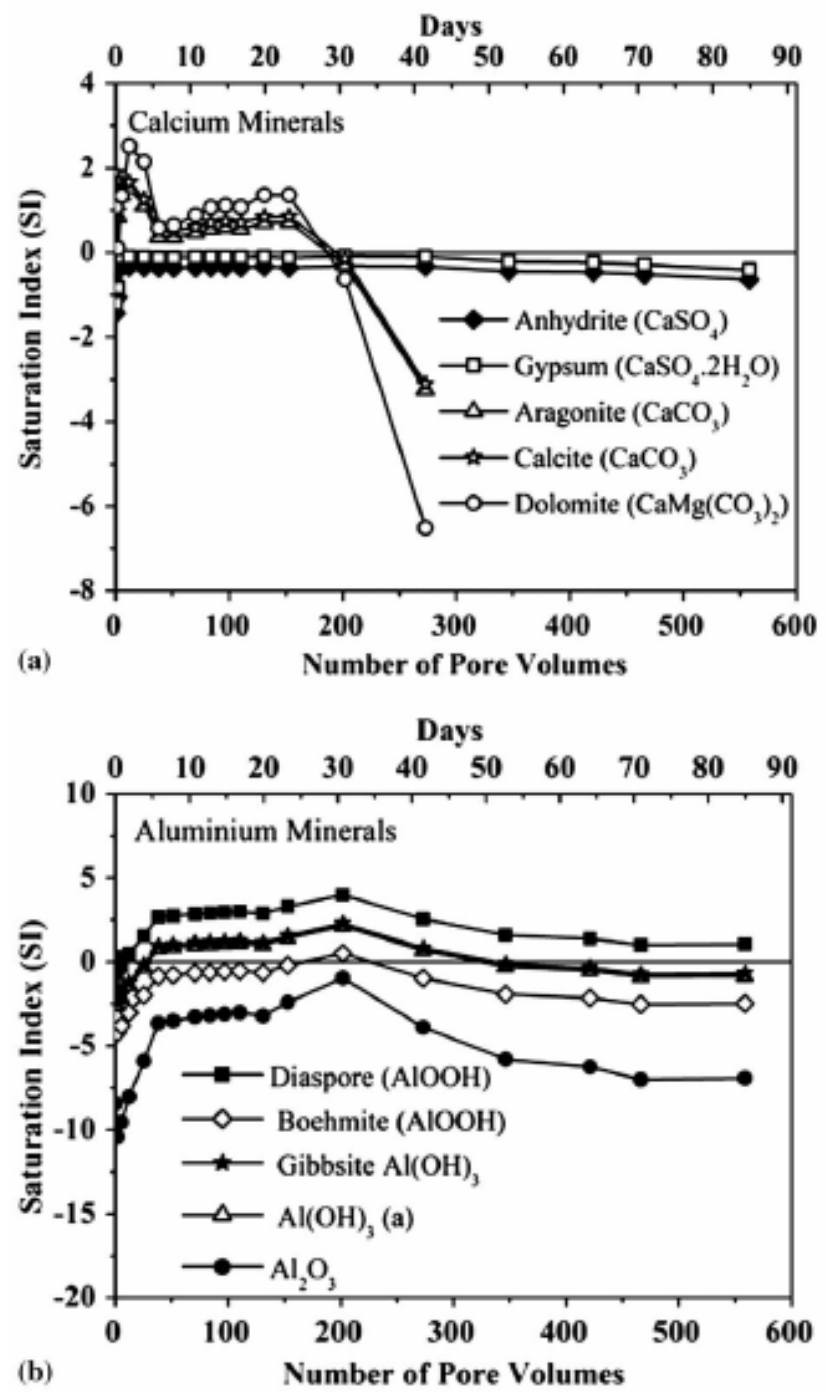

(b)

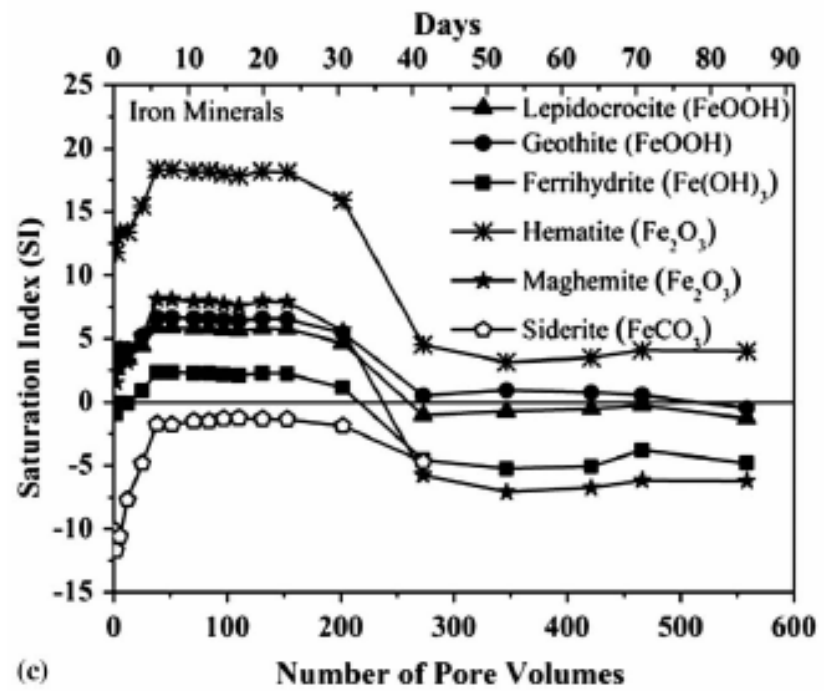

Fig. 8. Saturation indexes (SIs) of different minerals calculated using PHREEQC with respect to the number of pore volumes of synthetic acidic groundwater passed in Column A and time 

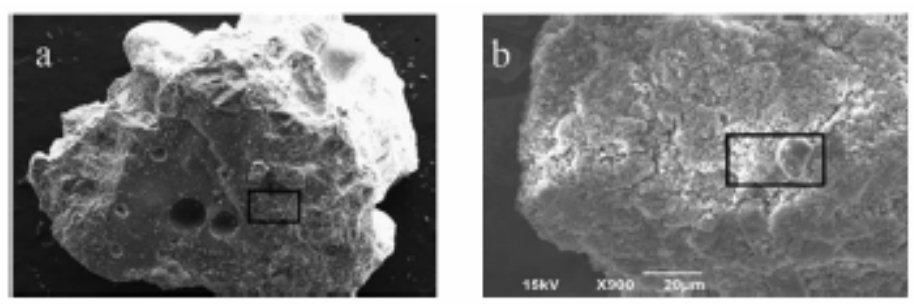

Fig. 9. Scanning electron microscopic (SEM) images of (a) virgin recycled concrete before the experiment and (b) armored concrete from Column A after the completion of the experiment.

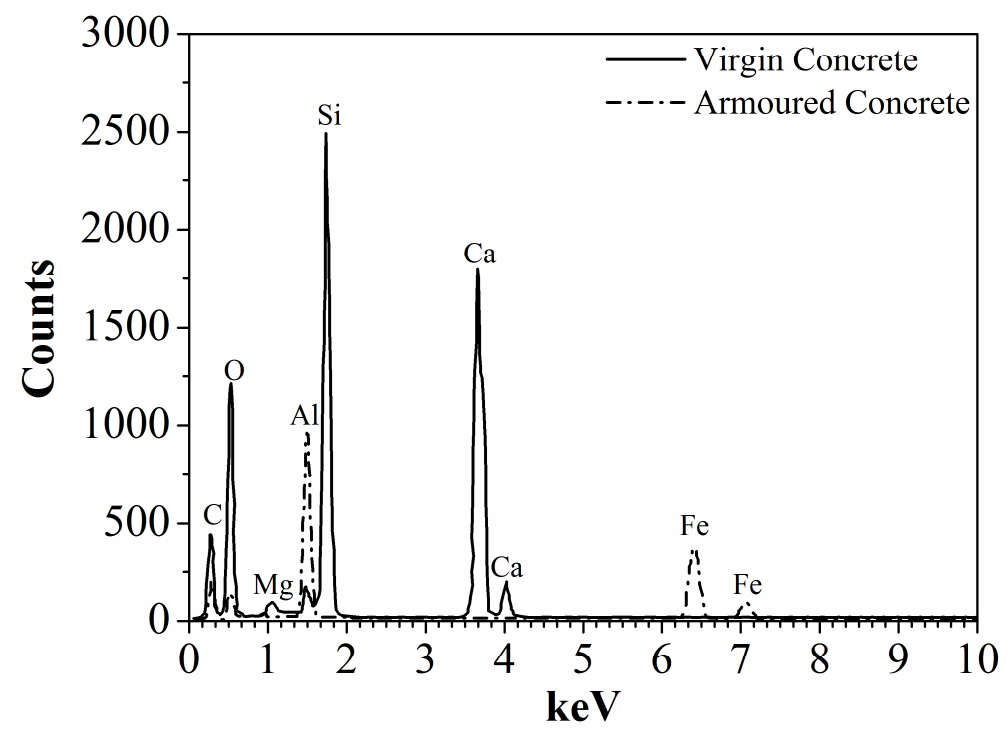

Figure 10: Electron dispersive spectroscopic (EDS) analysis of the recycled concrete used in column experiment A (solid line represents the virgin concrete before the experiment and the dash line represents the armoured concrete after the experiment)

In order to investigate which minerals were saturated over the duration of the experiment, SI of minerals in equilibrium with the effluent were calculated as a function of pore volumes (Fig. 8) using PHREEQC V 2.15 (Parkhurst and Appleo 1999). For $50<\mathrm{PV}<200$, when the pH was stable $(\mathrm{pH} 7.9-6.5)$, the effluent was slightly supersaturated with respect to carbonate minerals (Fig.8a), suggesting continuous release of calcium from the concrete. This trend indicates that a small amount of $\mathrm{Ca}$ might have been re-precipitated as carbonate minerals (e.g. aragonite, calcite, and dolomite) during the early period. This is supported by the observed 6.6 $\mathrm{g} / \mathrm{kg}, 5.3 \mathrm{~g} / \mathrm{kg}$ and $12.1 \mathrm{~g} / \mathrm{kg} \mathrm{Ca}$ in the precipitates collected from 0-10 cm, 10-30 $\mathrm{cm}$ and 30-50 $\mathrm{cm}$ along the length of the column. Interestingly, gypsum remained unsaturated throughout the 
study period with no sign of its precipitation inside the column, unlike the observations of Jurjovec et al. (2002) and Komnitsas et al (2004). This difference was likely due to insufficient amounts of sulphate present in the synthetic acidic groundwater to exceed the equilibrium of gypsum. This supposition is supported by a previous study involving another passive treatment system where the level of $\mathrm{SO}_{4}{ }^{2-}$ required for gypsum precipitation was $>2000 \mathrm{mg} / \mathrm{L}$ (Robbins et al. 1999).

The calculated SIs of the effluent also demonstrate that the effluent was saturated with respect to $\mathrm{Al}$ minerals (gibbsite, boehmite and diaspore) and Fe minerals (hematite, maghemite, goethite, lepidocrocite, ferrihydrite) in the first 200-250 PVs when the $\mathrm{pH}$ was almost neutral (Figs. 8b,c). These results indicate that the precipitation of $\mathrm{Al}$ and $\mathrm{Fe}$, mainly as oxides, oxyhydroxides, and hydroxides, was common during the first $\mathrm{pH}$ plateau. This precipitation was evidenced by (a) observation of white and orange precipitates grown inside the column, (b) clearly distinguished peaks of $\mathrm{Al}$ and Fe in the SEM images (Fig. 9) of armoured concrete compared to the virgin concrete, as shown by SEM-EDS analysis (Fig. 10), and (c) high levels of both $\mathrm{Fe}(138-231 \mathrm{~g} / \mathrm{kg})$ and $\mathrm{Al}(67-143 \mathrm{~g} / \mathrm{kg})$ observed in the elementary analysis of the precipitates from column A (Table 2). Similarly, previous studies of field installations of PRBs and column tests also report precipitates of ferrous/ferric (oxy/hydroxide) oxides and aluminium hydroxides (Mackenzie et al. 1999; Puls et al. 1999; Vogan et al. 1999; Phillips et al. 2000; Roh et al. 2000; Golab et al. 2009 ).

\section{Aluminium oxy/hydroxide buffering}

In column $\mathrm{A}$, after a rapid drop in $\mathrm{pH}$ between $250 \mathrm{PV}$ and $300 \mathrm{PV}$, the $\mathrm{pH}$ stabilised at $\mathrm{pH} \sim 4$ for $300<\mathrm{PV}<480$ (Fig. 4a). This plateau was possibly due to the equilibrium attained by the redissolution of aluminium precipitates at $\mathrm{pH} \sim 4.3-4.0$, similar to that reported by Blowes et al. (2003) and Jurjovec et al. (2002) for acid mine drainage. The results of equilibrium modelling also showed that the column effluent became slightly under-saturated with respect to gibbsite and boehmite during this period (Fig. 8b). Eventually, however, the masses of these two minerals (gibbsite and boehmite) were not sufficient to buffer the acidic water continuously passing through the column. Accordingly, the dissolved concentration of Al steadily increased during this period, eventually reaching that of the influent (Fig. 7). 


\section{Ferric oxy/hydroxide buffering}

After the depletion of aluminium oxy/hydroxide buffering in column A, the $\mathrm{pH}$ dropped to 3.0 within the following $20 \mathrm{PVs}$ from the end of the second $\mathrm{pH}$ plateau ( $480 \mathrm{PVs})$, then slowly reached the influent $\mathrm{pH}$ of 2.67 at $\sim 580$ PVs (Fig. 5a). Johnson et al. (2000) suggested that goethite (ferric oxyhydroxide) can maintain a $\mathrm{pH}$ from 2.8 - 3 when close to equilibrium. In this study, hematite was supersaturated throughout the test in column A (Fig. 8c), indicating that some Fe continued to react with the dissolved oxygen in the system. However, the SIs of other Fe minerals (goethite and lepidocrocite) decreased rapidly to nearly zero after the first $\mathrm{pH}$ plateau at PV 250, but reached equilibrium and under-saturation after the second $\mathrm{pH}$ plateau at PV 500. These results suggest that, although some of the mass of the goethite can be attributed to maintaining the level of the third $\mathrm{pH}$ plateau, as evidenced by Johnson et al. (2000) and Blowes et al. (2003), the mass of goethite was insufficient to buffer the $\mathrm{pH}$ for an extended period with the continuous flow of acidic water. This interpretation is supported by (1) the steep decrease in effluent $\mathrm{pH}$ immediately after reaching equilibrium with Fe minerals at PV 500 and reaching the influent level at PV $\sim 580$ (Fig. 5a), and (2) the increase in the concentration Fe after reaching the third $\mathrm{pH}$ plateau at $500 \mathrm{PVs}$ (Fig.7b).

\section{MINERAL PRECIPITATION/DISSOLUTION}

White and/or bright orange precipitates, possibly corresponding to precipitates of aluminium and iron hydroxyl, were observed in this study. They began to form near the column inlet and then further up the column as the flow of acidic water continued through the columns. Initially, dark amorphous precipitates were observed in columns $\mathrm{A}$ and $\mathrm{B}$, which turned to a white milky coloured amorphous precipitates within a few days. Subsequently, bright orange precipitates were seen at the bottom of the columns A and B which grew upwards, following the white precipitates. In contrast, only the bright orange precipitate was observed in column $\mathrm{C}$ and white milky precipitates in column D. These distinct white and/or bright orange precipitates were recognised as $\mathrm{Al}$ and $\mathrm{Fe}$ minerals, respectively, based on the colour of the precipitates, the mass balance of the ions, the SIs of the minerals and SEM/EDS analysis. In addition, the chemical composition of the precipitates from column A, as shown in Table 2, confirmed that the major elements in the precipitates were $\mathrm{Al}$ and $\mathrm{Fe}$. However, the presence of other elements such as $\mathrm{Ca}$, $\mathrm{S}, \mathrm{Mg}$ and $\mathrm{C}$ (Table 2) also indicated possible co-precipitation of other minerals such as dolomite 
$\left(\mathrm{CaMg}\left(\mathrm{CO}_{3}\right)_{2}\right)$. Only small amounts of these minerals likely formed, because their levels in the precipitates were very low. In addition, since there was no significant reduction in the concentration of $\mathrm{Mg}^{2+}, \mathrm{K}^{+}, \mathrm{Cl}^{-}$and $\mathrm{SO}_{4}{ }^{2-}$ compared to the concentration of $\mathrm{Al}$ and $\mathrm{Fe}$ in the effluent (Figs. 6 and 7), $\mathrm{Al}$ and Fe minerals (presumably combined with $\mathrm{O}$ and $\mathrm{H}$ ) were the major precipitates formed during these acid neutralisation reactions.

Based on data shown in Table 2, the amount of Al precipitated towards the bottom of column A was nearly half that towards the top of the column, suggesting re-dissolution of some of the $\mathrm{Al}$ minerals that precipitated during the early phase of the experiment from the bottom of the column. This supposition was supported by a rapid depletion of alkalinity and $\mathrm{pH}$ towards the bottom of the column for $83 \leq \mathrm{PV} \leq 300$ at all sampling points. These re-dissolved minerals were re-precipitated towards the top due to alkalinity present in the upper part, while the $\mathrm{pH}$ was maintained above 4.0, which resulted in large amounts of Al precipitates towards the top part of the column.

In contrast, although large amounts of Fe were precipitated throughout the column, the mass of the Fe precipitate was higher in the bottom half. As the $\mathrm{pH}$ in the bottom half of the column was maintained above the buffering point of ferric hydroxides (i.e. above $\mathrm{pH} 2.8$ ) by bicarbonate and $\mathrm{Al}$ buffering for large PVs of acid passed (up to $~ 480 \mathrm{PV}$ ), the Fe in the bottom half precipitated continuously until the Al buffering was depleted. Since the experiment was stopped 100 PVs after the Al buffering depleted, the Fe minerals likely did not have sufficient time to re-dissolve.

\section{METAL REMOVAL CAPACITY}

The near-neutral $\mathrm{pH}$ maintained by the carbonate/bicarbonate buffering in the system favoured precipitation of $\mathrm{Al}$ and $\mathrm{Fe}$ in different oxides, oxyhydroxides and hydroxides. The concentrations of $\mathrm{Al}$ and $\mathrm{Fe}$ in column A started to increase after 250 and $480 \mathrm{PVs}$, respectively, corresponding to a decrease in $\mathrm{pH}$ from near-neutral $(\mathrm{pH} \sim 6.5)$ to acidic conditions $(\mathrm{pH} \leq 4.0)$, when the alkalinity was totally depleted. Similar observations were also apparent in the other columns.

Although the capacity to remove $\mathrm{Al}$ and Fe decreased over time, there was more $\mathrm{Al}$ in the effluent than Fe during the entire experiment, possibly due to $\mathrm{pH}$-dependent solubility, because the lower limits of $\mathrm{pH}$ for precipitating $\mathrm{Al}$ and $\mathrm{Fe}$ are $\mathrm{pH} 4.0$ and 3.5, respectively. Alternatively, this may indicate that Fe selectively precipitates onto the surface of the concrete. Another 
possibility is that the acidic influent liberated Al from the concrete (Fig. 2). Nevertheless, the results confirmed that recycled concrete could effectively remove both $\mathrm{Al}$ and $\mathrm{Fe}$ from large volumes of synthetic groundwater while maintaining almost neutral $\mathrm{pH}$ in the system.

\section{NEUTRALISATION CAPACITY/REACTIVITY}

Decreases in the reactivity and hydraulic properties of the reactive material are the most important factors in the prediction of the longevity/long-term performance of reactive materials. Several studies have reported that a major limitation of PRBs is not the exhaustion of the reactive material, but rather chemical armouring and clogging of the pore spaces through mineral precipitation and accumulation on the surface of the reactive media and within the pore spaces, respectively (Mackenzie et al. 1999; Phillips et al. 2000; Kamolpornwijit et al. 2003; Li et al. 2005; Li et al. 2006). Column tests offer a controlled system in which to study the behaviour of armouring and clogging.

Fouling by precipitates might significantly decrease the reactivity (acid neutralisation and metals removal capacity) of the materials, although part of their reactivity would already have decreased to some extent by the exhaustion of the alkalinity of the materials in the acid neutralisation process. A comparison between the SEM images of the virgin and the armoured recycled concrete used in the column experiment (Fig. 9) showed significant amounts of mineral precipitation over the surface of the recycled concrete, which supports this supposition. In this study, decrease in reactivity by armouring was studied with respect to the material's ANC efficiency which was calculated as the ratio of the actual ANC of the material to the theoretical ANC.

Figure 4 shows that the $\mathrm{Al}$ and/or Fe removal capacity of the recycled concrete was very high until bicarbonate buffering ceased, as discussed in the previous section, where every column displayed a similar trend of $\mathrm{Al}(>99 \%)$ and/or Fe (100\%) removal in the first plateau stage. These results show that acid neutralisation reactions along with the major precipitation of minerals occurred only during the carbonate/bicarbonate buffering period (i.e., first pH plateau).

Fig. 4 also illustrates that $\mathrm{Al}$ concentration started to increase rapidly after the depletion of bicarbonate buffering and reached the influent concentration during the aluminium hydroxide buffering period. However, effluent Fe concentration remained $<0.5 \mathrm{mg} / \mathrm{L}$ during the aluminium hydroxide buffering period, but started to increase only after the depletion of aluminium 
hydroxide buffering. The results indicate that $\mathrm{Al}$ removal capacity decreased rapidly from $>99 \%$ to $0 \%$ after the first $\mathrm{pH}$ plateau compared with the Fe removal capacity. Therefore, the PV corresponding to the end of the first plateau in $\mathrm{pH}$ at near neutral value, when the reactive material could no longer remove $100 \%$ of the $\mathrm{Al}$ and/or $\mathrm{Fe}$, was considered to be an inflection point for analysing the ANC efficiency of the material in these experiments. Consequently, actual ANC was measured as the number of PVs of acidic water treated before the $\mathrm{pH}$ fell below the near neutral value (PVs corresponding to the end of $1^{\text {st }}$ plateau), and the theoretical ANC was the total PVs of the acid that the material should treat without armouring.

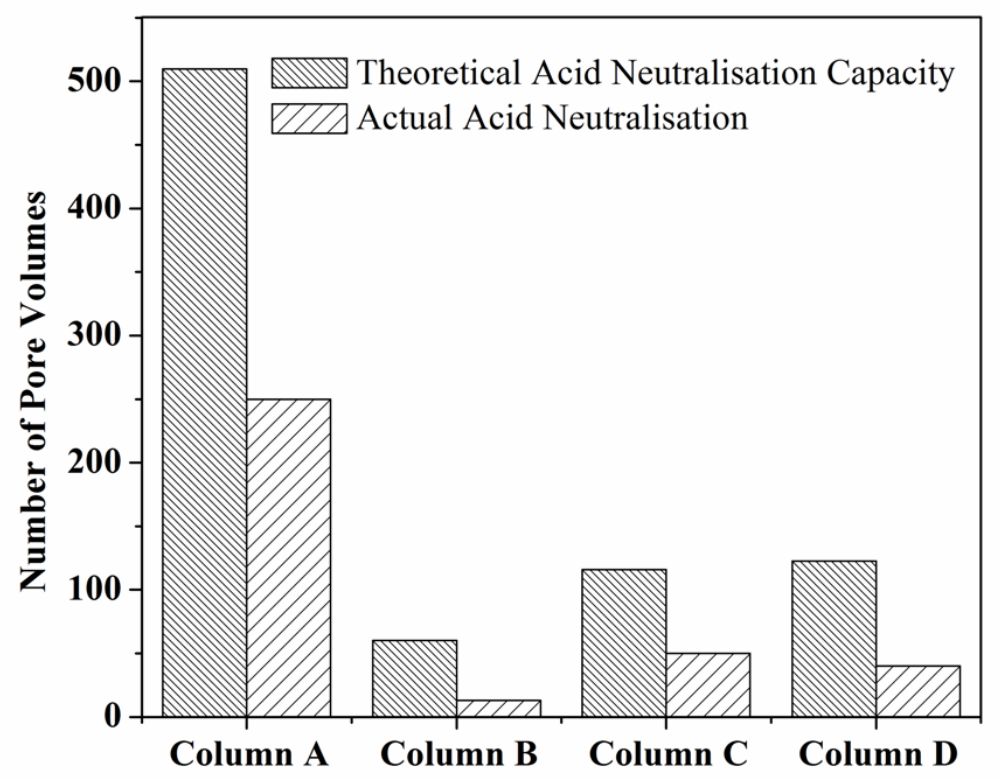

Figure 11: Acid neutralisation capacity of the recycled concrete under different concentrations of Fe and Al.

Comparison of the actual and theoretical ANC of the four columns was illustrated in Fig. 11. Columns A, B, C and D treated 252, 13, 50 and $40 \mathrm{PVs}$ of acidic water. However, the theoretical ANC of the concrete until the complete depletion of alkalinity without armouring was 510, 60.2, 115.9 and 122.7 PVs respectively for columns A, B, C and D. The results show that the loss in the ANC efficiency of the reactive material by armouring was very high ( $>50 \%$ in all cases) compared to the loss of ANC efficiency by exhaustion of alkalinity. Furthermore, the loss in ANC efficiency was faster in the columns with greater $\mathrm{Al}$ and $\mathrm{Fe}$ influent concentrations (Table 1) because these cations precipitated onto the surface of the reactive material. This 
observation was supported by evidence of a rapid increase in $\mathrm{Al}$ and Fe in the effluent shortly after the $\mathrm{pH}$ drop from almost neutral $\mathrm{pH}$ (Fig. 4).

Thus, the overall results from the column experiments (Figs. 4 and 11) show that armouring has a greater impact on decreasing the reactivity of the recycled concrete over a short period of time (e.g.: 252, 13, 50 and 40 PVs in columns A, B, C and D respectively) than does depletion of alkalinity (510, 60.2, 115.9 and 122.7 PVs in columns A, B, C and D respectively). In addition, the overall capacity of the material for maintaining a near-neutral $\mathrm{pH}$ and $100 \%$ removal of $\mathrm{Fe}$ and $\mathrm{Al}$ depends on the concentrations of these cations, i.e. the higher the concentration, the higher the decrease in ANC efficiency. However, despite the massive decrease in ANC efficiency due to armouring, the material still demonstrated good performance for neutralising the $\mathrm{pH}$ and removing $\mathrm{Fe}$ and $\mathrm{Al}$ for large PVs of acidic groundwater (Fig.4).
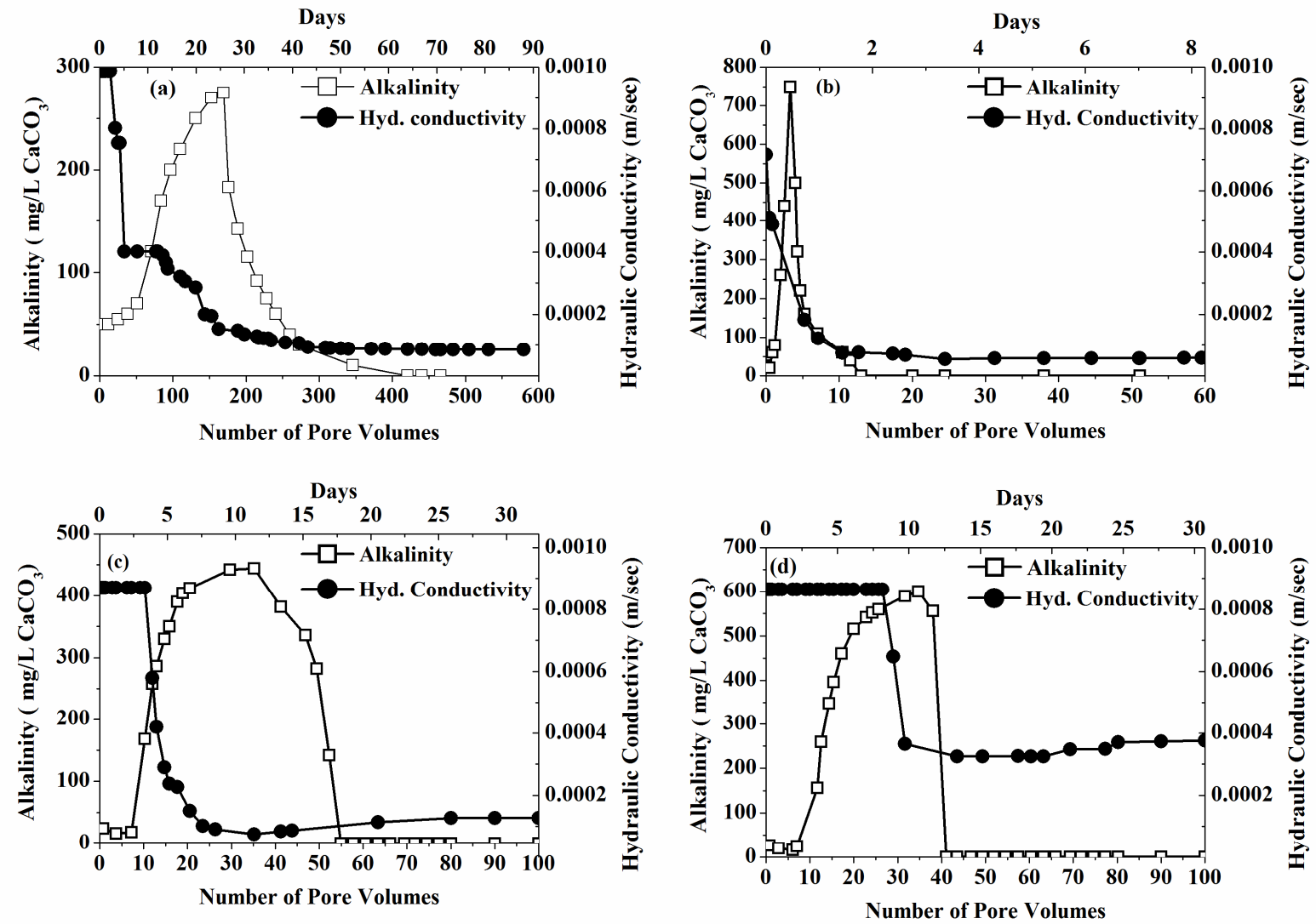

Figure 12: Decrease in alkalinity and hydraulic conductivity of the column material with respect to the number of pore volumes of acid passed and time (a-d represents the columns A-D). 


\section{CHANGES IN PHYSICAL PROPERTIES}

In addition to armouring the surface of the reactive material, the pores of the PRB will be filled with accumulated precipitates; thus subsequently reducing hydraulic flux through the PRB (Li et al 2006). Several authors have reported that clogging may occur excessively near the inlet of the reactive materials and not homogeneously throughout the column (Kamolpornwijit et al. 2003; Li and Benson 2005; Bilek 2006). Similarly, slightly larger amounts of precipitates formed towards the bottom half of column A (zones 1 and 2) rather than top half (zone 3) (Table 2), showing that the precipitates were not distributed homogenously in the pore space and that their composition differed with distance along the column.

Because the use of a peristaltic pump forced a constant flow rate through the columns; the clogging phenomenon was studied by monitoring the change in hydraulic conductivity with respect to the number of PVs of acid passed through the columns. As shown in Fig. 12 for columns A, C and D, the hydraulic conductivity was fairly constant for the first few PVs $(\sim 20$, $\sim 10$ and $\sim 26$ PVs, respectively) and then decreased rapidly until the bicarbonate alkalinity was exhausted. But, in column B, the hydraulic conductivity decreased rapidly from the beginning until the bicarbonate alkalinity was exhausted because of rapid precipitation due to the combination of higher concentration of the influent with high flow rate. In addition, the porosity was lower in column B (48\%) compared to columns A (53\%), C (56\%) and D (55\%).

The decrease in hydraulic conductivity was due to the formation of the precipitation front in the pore spaces parallel with the flow. After the depletion of bicarbonate alkalinity, the hydraulic conductivity remained almost constant due to a lack of major buffering reactions to cause the minerals to precipitate, as discussed in the section on acid neutralisation behaviour. In columns $\mathrm{C}$ and $\mathrm{D}$, there was a slight increase in hydraulic conductivity after reaching the $2^{\text {nd }} \mathrm{pH}$ plateau, which may have been caused by the re-dissolution of the aluminium and ferric oxy/hydroxide precipitates, respectively. The difference was particularly evident in Column D, which only contained $\mathrm{Al}$ and maintained a much higher hydraulic conductivity than the other 3 columns. Such a slight increase in hydraulic conductivity in column D indicated that the redissolution of $\mathrm{Al}$ precipitates was more common than Fe precipitates, as expected from the difference in $\mathrm{pH}$ of precipitation for these two cations. Even the diminished hydraulic conductivity of the columns was higher than the hydraulic conductivity of the natural clay seit in 
the vadose zone of ASS Terrain. The pores in the column were large, due to the size of the column fill and the system did not fail completely from pore clogging even though preferential flow occurred to some extent. When the grains in the PRB are considered to be even bigger than those in the column, the difference in hydraulic conductivity between the PRB and soil should ensure that a loss of porosity due to clogging is unlikely to threaten the longevity of the PRB.

\section{CONCLUSIONS}

This paper presents the longevity study of the recycled concrete used in the permeable reactive barrier for treatment of acidic groundwater in acid sulphate soil terrains of coastal Australia. Four laboratory column tests were conducted to evaluate the acid neutralisation mechanisms and assess the capacity of recycled concrete for treating acidic water from acid sulphate soils under accelerated flow conditions. The results of the study confirmed that the treatment mechanism is mainly controlled by the release of carbonate/bicarbonate alkalinity into the system, and the precipitation of $\mathrm{Al}$ and $\mathrm{Fe}$ in different oxide, oxy-hydroxide and hydroxide minerals. The experimental results show that the recycled concrete can maintain an almost neutral $\mathrm{pH}$ for long periods and remove $100 \%$ of the $\mathrm{Fe}$ and $\mathrm{Al}$.

The effectiveness of recycled concrete for treating the acidic water was assessed with respect to the number of pore volumes of acidic water passed until the $\mathrm{pH}$ dropped below nearneutral values and from when the concentrations of $\mathrm{Al}$ and Fe began to increase. The results showed that the precipitated $\mathrm{Al}$ and Fe minerals coated the surface of the reactive material, which significantly reduced its long-term ANC efficiency and furthermore, high loads of $\mathrm{Al}$ and Fe caused a rapid decrease in ANC efficiency due to accelerated armouring. In addition, application of larger size concrete aggregates has reduced the threat of clogging by accumulation of precipitates in the pore spaces even under high concentrations of dissolved $\mathrm{Al}$ and $\mathrm{Fe}$ in the influent. Nevertheless, because the material performed effectively when neutralising acid and removing $\mathrm{Al}$ and $\mathrm{Fe}$ in a simulated acidic environment even while armoured, recycled concrete may be a suitable material in PRBs for the treatment of acidic water in ASS terrain . However, the longevity of the PRB will depend on real-time duration of reactivity of the material used, with or without armouring, relative to metal loading.

\section{ACKNOWLEDGEMENTS}


The authors would like to acknowledge Glenys Lugg (Manildra Group), Bob Rowlan and Andreas Dillman (University of Wollongong) for their assistance during this study. Assistance of Dr. Laura Banasiak (Research Fellow at UOW) is gratefully appreciated. The first author's PhD study was sponsored through the Endeavour Scholarship Scheme by the Australian Government.

\section{REFERENCES}

Ahern, C. R., McElnea, A., and Sullivan, L. (2004). "Acid Sulfate Soils Laboratory Methods Guidelines." Queensland Department of Natural Resources, Mines and Energy, Indooroopilly, Queensland, Australia

Al, T. A., Martin, C. J., and Blowes, D. W. (2000). "Carbonate-mineral/water interactions in sulfide-rich mine tailings." Geochimica et Cosmochimica Acta, 64(23), 3933-3948.

APHA (1998). Standard Methods for the Examination of Water and Wastewater, 20th Edition, American Public Health Association, Washington.

ASTM D2487 (2000). Standard Practice for classification of soils for engineering purposes (Unified Soil Classification System).American Society for Testing and Materials, Pennsylvania.

Benner, S. G., Blowes, D. W., Gould, W. D., Herbert Jr, R. B., and Ptacek, C. J. (1999). "Geochemistry of a permeable reactive barrier for metals and acid mine drainage." Environmental Science \& Technology, 33, 2793-2799.

Bilek, F. (2006). "Column tests to enhance sulphide precipitation with liquid organic electron donators to remediate AMD-influenced groundwater." Environmental Geology, 49, 674683.

Blowes, D. W., Ptacek, C. J., Benner, S. G., McRae, C. W. T., Bennett, T. A., and Puls, R. W. (2000). "Treatment of inorganic contaminants using permeable reactive barriers." Journal of Contaminant Hydrology, 45(1-2), 123-137.

Blowes, D. W., Ptacek, C. J., Jambor, J. L., and Weisener, C. G. (2003). "The Geochemistry of Acid Mine Drainage." Treatise on Geochemistry, H. D. H. a. K. K. Turekian, ed., Elsevier Science Ltd, Oxford, 149-204. 
Blunden, B., and Indraratna, B. (2001). "Pyrite oxidation model for assessing ground-water management strategies in acid sulfate soils." Journal of Geotechnical and Geoenvironmental Engineering, ASCE, 127(2), 146-157.

Glamore, W., and Indraratna, B. (2004). "A two-stage decision support tool for restoring tidal flows to flood mitigation drains affected by acid sulphate soil: case study of Broughton Creek Floodplain, New South Wales, Australia." Australian Journal of Soil Research, 42, 639-648.

Golab, A., Peterson, M., and Indraratna, B. (2009). "Selection of permeable reactive barrier materials for treating acidic groundwater in acid sulphate soil terrains based on laboratory column tests." Environmental Earth Sciences, 59(1), 241-254.

Golab, A. N., and Indraratna, B. (2009). "Occurrence and consequences of acid sulphate soils and methods of site remediation." Geomechanics and Geoengineering, 4(3), 201-208.

Golab, A. N., Peterson, M. A., and Indraratna, B. (2006). "Selection of potential reactive materials for a permeable reactive barrier for remediating acidic groundwater in acid sulphate soil terrains." Quarterly Journal of Engineering Geology and Hydrogeology, 39, 209-223.

Gu, B., Watson, D. B., Phillips, D. H., and Liang, L. (2002). "Biogeochemical, mineralogical, and hydrological characteristics of an iron reactive barrier used for treatment of uranium and nitrate." Handbook of Groundwater Remediation Using Permeable Reactive Barriers: Applications to Radionuclides, Trace Metals, and Nutrients, D. L. Naftz, S. J. Morrison, C. C. Fuller, and J. A. Davis, eds., Academic Press, San Francisco, 305-342.

Indraratna, B., Golab, A., Glamore, W., and Blunden, B. (2005). "Acid sulphate soil remediation techniques on the Shoalhaven River Floodplain, Australia." Quarterly Journal of Engineering Geology and Hydrogeology, 38, 129-142.

Johnson, R. H., Blowes, D. W., Robertson, W. D., and Jambor, J. L. (2000). "The hydrogeochemistry of the Nickel Rim mine tailings impoundment, Sudbury, Ontario." Journal of Contaminant Hydrology, 41(1-2), 49-80.

Jurjovec, J., Ptacek, C. J., and Blowes, D. W. (2002). "Acid neutralization mechanisms and metal release in mine tailings: a laboratory column experiment." Geochimica et Cosmochimica Acta, 66(9), 1511-1523. 
Kamolpornwijit, W., Liang, L., West, O. R., Moline, G. R., and Sullivan, A. B. (2003). "Preferential flow path development and its influence on long-term PRB performance: column study." Journal of Contaminant Hydrology, 66(3-4), 161-178.

Komnitsas, K., Bartzas, G., and Paspaliaris, I. (2004). "Efficiency of limestone and red mud barriers: laboratory column studies." Minerals Engineering, 17(2), 183-194.

Li, L., and Benson, C. H. (2005). "Impact of fouling on the long-term hydraulic behaviour of permeable reactive barriers." IAHS-AISH Publication(298), 23-31.

Li, L., Benson, C. H., and Lawson, E. M. (2005). "Impact of Mineral Fouling on Hydraulic Behavior of Permeable Reactive Barriers." Ground Water, 43(4), 582-596.

Li, L., Benson, C. H., and Lawson, E. M. (2006). "Modeling porosity reductions caused by mineral fouling in continuous-wall permeable reactive barriers." Journal of Contaminant Hydrology, 83(1-2), 89-121.

Mackenzie, P. D., Horney, D. P., and Sivavec, T. M. (1999). "Mineral precipitation and porosity losses in granular iron columns." Journal of Hazardous Materials, 68(1-2), 1-17.

Parkhurst, D. L., and Appelo, C. A. J. (1999). "User's Guide to Phreeqc (Version 2) - A Computer Program for Speciation, Batch-Reaction, One-Dimensional Transport, and Inverse Geochemical Calculations." Water-Resources Investigations Report 99-4259, U.S. Geological Survey Water-Resources Investigations Report 99-4259, Denver, Colorado.

Phillips, D. H., Gu, B., Watson, D. B., Roh, Y., Liang, L., and Lee, S. Y. (2000). "Performance evaluation of a zerovalent iron reactive barrier: Mineralogical characteristics." Environmental Science \& Technology, 34(19), 4169-4176.

Puls, R. W., Blowes, D. W., and Gillham, R. W. (1999). "Long-term performance monitoring for a permeable reactive barrier at the U.S. Coast Guard Support Center, Elizabeth City, North Carolina." Journal of Hazardous Materials, 68(1-2), 109-124.

Regmi, G., Indraratna, B., and Nghiem, L. D. (2009). "Long-term Performance of a Permeable Reactive Barrier in Acid Sulphate Soil Terrain." Water, Air, \& Soil Pollution: Focus 9, 409-419.

Robbins, E. I., Cravotta, C. A., III, Savela, C. E., and Nord, G. L., Jr. (1999). "Hydrobiogeochemical interaction in "anoxic" limestone drains for neutralization of acidic mine drainage." Fuel, 78, 259-270. 
Roh, Y., Lee, S. Y., and Elless, M. P. (2000). "Characterization of corrosion products in the permeable reactive barriers." Environmental Geology, 40(1-2), 184-194.

Sammut, J., White, I., and Melville, M. D. (1996). "Acidification of an estuarine tributary in eastern Australia due to drainage of acid sulfate soils." Marine and Freshwater Research, 47(5), 669-684.

Singer, P. C., and Stumm, W. (1970). "Acidic mine drainage: the rate-determining step." Science, (167), 1121.

Tam, V. W. Y., Gao, X. F., and Tam, C. M. (2005). "Carbonation around near aggregate regions of old hardened concrete cement paste." Cement and Concrete Research, 35(6), 11801186.

Vogan, J. L., Focht, R. M., Clark, D. K., and Graham, S. L. (1999). "Performance evaluation of a permeable reactive barrier for remediation of dissolved chlorinated solvents in groundwater." Journal of Hazardous Materials, 68(1-2), 97-108.

Watzlaf, G. R., Schroeder, K. T., and Kairies, C. (2000). "Long-term performance of anoxic limestone drains for the treatment of mine drainage." Mine Water and the Environment, 19, 98-110.

Waybrant, K. R., Ptacek, C. J., and Blowes, D. W. (2002). "Treatment of mine drainage using permeable reactive barriers: column experiments." Environmental Science \& Technology, 36(6), 1349-1356.

White, I., Melville, M. D., Wilson, B. P., and Sammut, J. (1997). "Reducing acidic discharges from coastal wetlands in eastern Australia." Wetlands Ecology and Management, 5(1), $55-72$. 